\title{
Rancangan Sistem Informasi Manajemen Aset di PT. Sentral Tukang Indonesia
}

\author{
Muhammad Ridwan', ${ }^{1}$, Muhammad $^{2}$, Siti Ramadhani ${ }^{3}$ \\ ${ }^{1,2}$ Manajemen Informatika, AMIK Mahaputra Riau \\ Jl. HR. Soebrantas No.77 Tampan, Pekanbaru 28294 \\ ${ }^{3}$ Teknik Informatika UIN Sultan Syarif Kasim Riau \\ Jl. H.R. Soebrantas no. 155 KM. 18 Simpang Baru, Pekanbaru 28293 \\ muhammad_ridwan@gmail.com ${ }^{1}$, muhammad@amikmahaputra.ac.id ${ }^{2}$, siti.ramadhani@uin-suska.ac.id ${ }^{3}$
}

\begin{abstract}
Abstrak - Sentral Tukang Indonesia adalah perusahaan retail yang menjual aksesoris bangunan yang beralamat di Jl. Riau No.131 CD, Pekanbaru. Sentral Tukang saat ini menghadapi masalah dalam manajemen aset dari proses perawatan aset karena masih menggunakan ingatan perorangan saja sedangkan asetnya banyak. Jika perorangan tersebut terlupa akan menjadi masalah apalagi terkait jenis aset yang melakukan pembayaran dan jika terlambat akan dikenakan denda. Penelitian ini untuk memudahkan sentral tukang untuk melakukan pencatatan perawatan aset perusahaan tersebut. Penelitian ini dibuat dengan menggunakan Visual Basic 6.0 sebagai program aplikasi desktop dan MySQL sebagai aplikasi databasenya. Proses penelitian dilakukan observasi dikarena penulis juga bekerja di sentral tukang selama setahun dan penulis mendapatkan masalah aset ini. Tahap pembuatan aplikasi ini yaitu analisa kelemahan sistem lama, pencarian data, perancangan, pembuatan, pengetesan, dan implementasi dari perancangan sistem informasi manajemen aset di sentral tukang. Hasil dari penelitian ini program desktop yang mengelola pencatatan perawatan aset dan juga sebagai pengingat akan perawatan aset-aset yang berada di Sentral Tukang.
\end{abstract}

Kata Kunci - Sistem Infomasi, Manajemen Aset, Perawatan Aset

\section{PENDAHULUAN}

Sistem manajemen aset adalah merupakan sistem informasi manajemen pendataan aset inventaris secara terintegrasi seluruh instansi dalam rangka melaksanakan tertib administrasi pengelolaan dan pendataan barang. Dengan sistem manajemen aset ini perusahaan dapat menentukan apa saja aset-aset yang telah ada di perusahaan serta dapat memperkirakan masa ekonomis suatu barang tersebut dengan perawatan yang teratur. Dalam hal ini sistem manajemen aset yang akan dibuat dapat mempermudah kerja melakukan pencatatan tentang aset-aset yang dimiliki perusahaan.
PT. Sentral Tukang Indonesia adalah perusahaan yang bergerak di bidang penjualan retail bahan bangunan dan alat-alat tukang. Sentral tukang memiliki beberapa cabang yang berada di Padang, Pekanbaru, dan Jambi. Banyaknya cabang tentu akan sulit untuk mengurus, merawat, serta menjaga asetaset yang di miliki oleh perusahaan tersebut. Asetaset yang ada sentral tukang antara lain : Mobil, Motor, Komputer, Printer, AC, Rak-rak display, Kursi, Meja Komputer, Meja Kasir dan alat-alat pendukung lainnya. Sepeda motor dan mobil mempunyai perawatan yang khusus yaitu Pajak, servis, SIU, dan perawatan berkala lainnya. Komputer, AC, printer dan alat-alat elekronik lainnya juga mempunyai perawatan khusus seperti $\mathrm{AC}$ harus diservice.

\section{METODOLOGI PENELITIAN}

Metode yang digunakan dalam melakukan pembuatan sistem ini adalah menganalisa hubungan keadaan data dan melakukan pengumpulan data dengan metode :

1. Penelitian Lapangan (Field Research)

Pada penelitian ini peneliti langsung melakukan riset lapangan pada PT. Sentral Tukang Indonesia mengadakan observasi, wawancara dengan pihak-pihak yang dianggap berkepentingan dalam masalah yang akan dibahas.

a. Bagaimana pengelolaan Aset di PT. Sentral Tukang Indonesia menjadi mudah dan cepat?

b. Bagaimana agar keterlambatan dalam pembayaran Pajak, SIU, Serta Servis di PT. Sentral Tukang Indonesia dapat di hindari?

c. Bagaimana mengetahui masa ekonomis atau masa pakai Komputer, Printer, AC, serta alat elektronik lainnya supaya tidak ada kesalahpahaman untuk pengadaan aset baru di PT. Sentral Tukang Indonesia?

2. Penelitian Perpustakaan (Library Research) Melakukan penelitian melalui buku-buku dan berbagai literatur yang berhubungan dengan tema dan topik dari laporan ini yang dapat 
digunakan sebagai pembahasan yang kompleks.

\section{Prosedur Sistem yang berjalan}

\section{ASI berjalan ASI (Aliran Sistem Informasi)}

Aliran sistem informasi yang sedang berjalan merupakan proses yang saat ini sedang di pakai oleh Sentral Tukang Pekanbaru dalam proses manajemen aset. Ada beberapa entitas yang saling berhubungan dalam aliran sistem informasi berjalan ini yaitu antara lain sebagai berikut :

a. Petugas/ supir dalam hal mobil meminta form laporan aset kepada MDS. MDS memberikan form laporannya.

b. Petugas mengisi form sesuai permintaan perawatan dan menandatanganinya. Lalu memberikan ke MDS

c. MDS meminta tanda tangan manager, manager menandatangani dan mengisi tindak lanjut yang akan dilakukan. setelah itu manager memberikan kepada MDS.

d. MDS memberi satu rangkap ke petugas, setelah persyaratan selesai dari segi uang dan persyaratan lainya. Petugas membawa aset tersebut ke bengkel atau ke jasa perawatan.

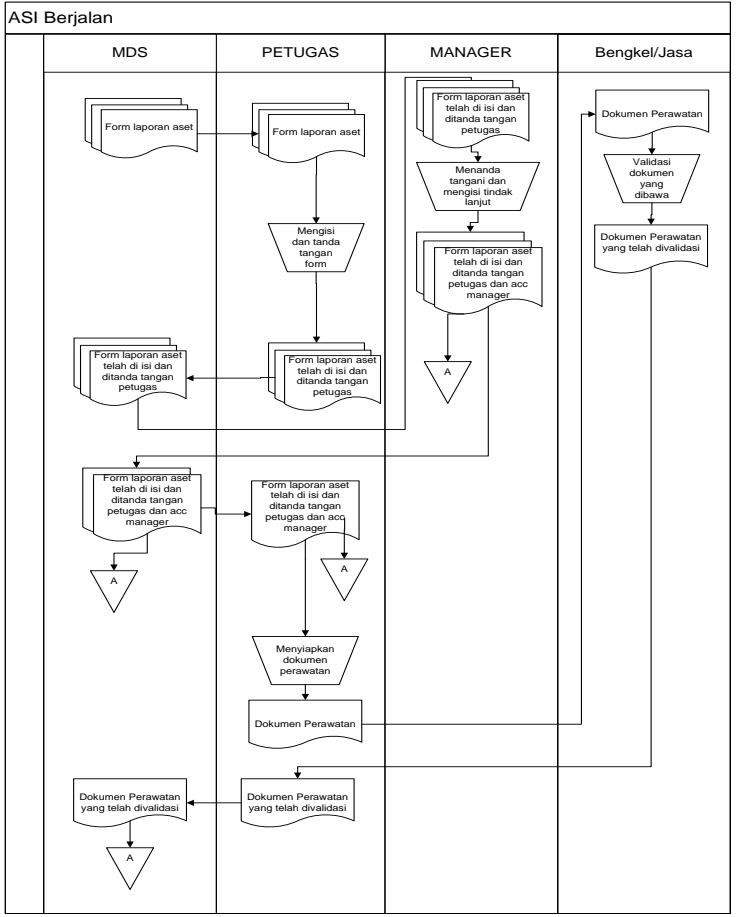

Gambar 1. ASI yang sedang berjalan

\section{ASI Usulan ( Aliran Sistem Informasi )}

Aliran sistem informasi yang diusulkan pada Sentral Tukang Indonesia Pekanbaru dalam proses manajemen aset. Ada beberapa entitas yang saling berhubungan dalam aliran sistem informasi yang diusulkan ini yaitu antara lain sebagai berikut:

a. MDS (Merchandiser) b. Admin/petugas

c. Manager

d. Jasa

Adapun sistem yang diusulkan sebagai berikut :

a. MDS menginput informasi tentang aset yang didapat dari berkas perawatan aset atau berkas dari pembelian aset baru.

b. Setelah informasi aset di simpan didalam database, maka otomatis akan ada pemberitahuan ketika mendekati tanggal perawatan atau mendekati data-data telah dimasukkan.

c. Lalu MDS membuat laporan perawatan aset, setelah disimpan akan otomatis muncul di pemberitahuan perangkat manager.

d. Lalu laporan yang telah di acc akan muncul pemberitahuan ke admin atau petugas untuk dilakukan tindakan selanjutnya. Admin/petugas ini yang akan pergi untuk mengurusi ke jasa atau bengkel. Sebelum itu admin mencetak laporan aset tersebut untuk kemudian diarsip.

e. Setelah aset dibawa atau hanya pembayaran pajak aset ke bengkel atau jasa. Lalu bengkel berkas informasi yang akan di input oleh MDS, admin memberi berkas tersebut ke MDS untuk dilakukan penginputan. Proses perawatan aset selesai sampai disini.

f. Selanjutnya jika aset telah mencapai masa ekonomis atau masa pakai sudah habis. Maka program otomatis memberi info tersebut, lalu dibuat laporan tersebut.

g. Lalu manager menvalidasi apakah aset ini masih bisa digunakan lagi atau tidak. Jika masih bisa digunakan, manager member pemberitahuan untuk perawatan aset selanjutnya. Jika tidak manager member untuk pemberitahuan untuk penghapusan aset.

h. Lalu salah satu pemberitahuan tersebut akan muncul di program di MDS, lalu jika penghapusan aset maka MDS akan membuat laporan penghapusan aset, jika perawatan lanjutan maka dimasukkan informasi baru.

Berikut ini adalah aliran sistem informasi yang diusulkan : 


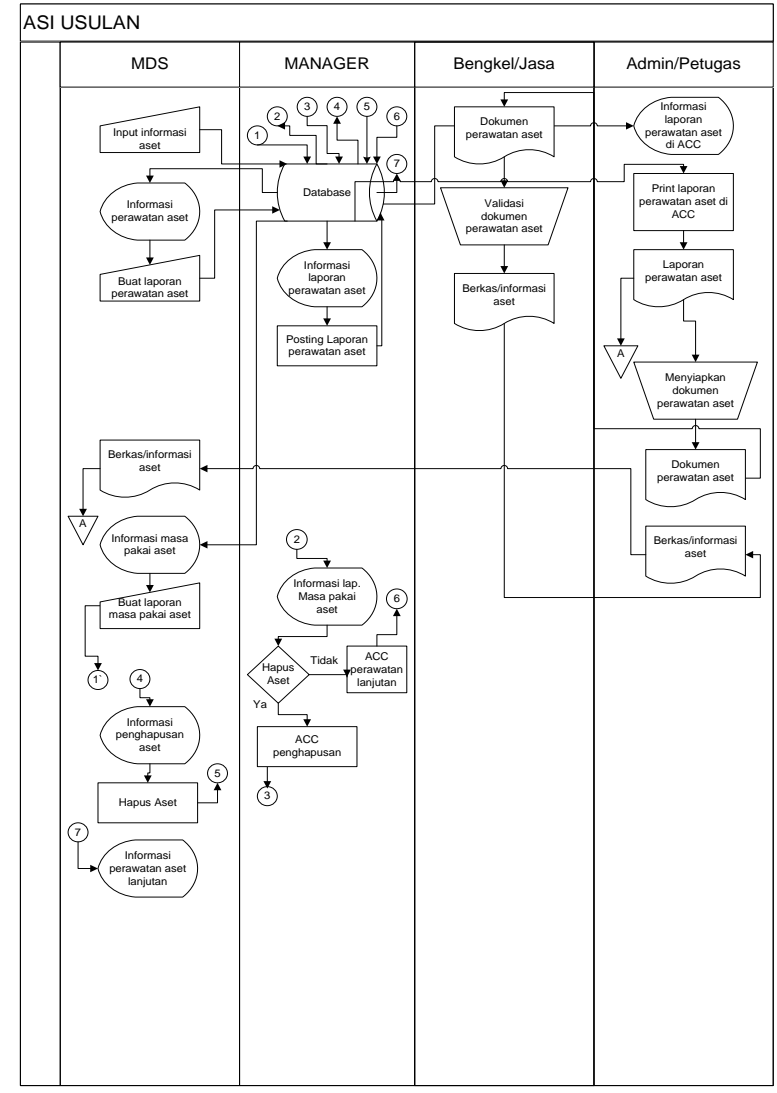

Gambar 2. Aliran Sistem Informasi yang Diusulkan

\section{CD ( Context Diagram )}

Conteks Diagram atau sebuah bagan yang menunjukkan sistem secara keseluruhan dan keterkaitan antara sistem dengan entitas luar yaitu terdiri dari :

a. MDS input infomasi aset, buat laporan perawatan aset, buat laporan masa pakai, menghapus aset, buat laporan perawatan lanjutan, selanjutnya sistem ini akan memberikan Info Perawatan Aset, Berkas/Info Aset, Info masa pakai Aset, Info penghapusan Aset, Info Perawatan Aset Lanjutan ke MDS.

b. Admin/petugas membawa Aset untuk lakukan perawatan, memberikan berkas/Informasi Aset selanjutnya sistem ini akan memberikan Info Laporan perawatan aset di ACC, Laporan perawatan aset, Berkas/informasi Aset.

c. Bengkel/jasa menerima perawatan/pembayaran aset, selanjutnya bengkel/jasa memberi berkas informasi aset.

d. Manager melakukan Laporan Perawatan Aset di ACC, ACC penghapusan Aset, ACC Perawatan Aset lanjutan. Sistem akan memberikan Info Laporan Perawatan Aset, Info Laporan masa pakai aset ke manager.
Adapun Context Diagram Sistem Manajemen Aset ini dapat dilihat di Gambar 3.

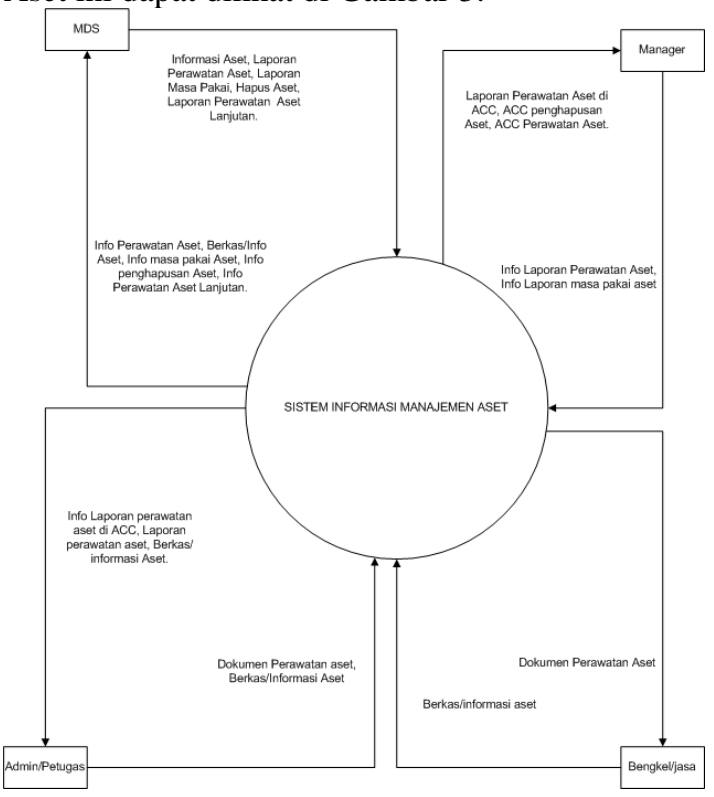

Gambar 3. Context Diagram

\section{DFD}

DFD adalah suatu diagram yang menggunakan notasi-notasi untuk menggambarkan arus dari data sistem yang penggunaannya sangat membantu untuk memahami sistem secara logika, terstruktur dan jelas yang dapat diakses oleh MDS, Admin/Petugas, dan Manager. Adapun DFD level 0 untuk Sistem Informasi Manajemen Sentral Tukang Indonesia dapat dilihat sebagai berikut : 


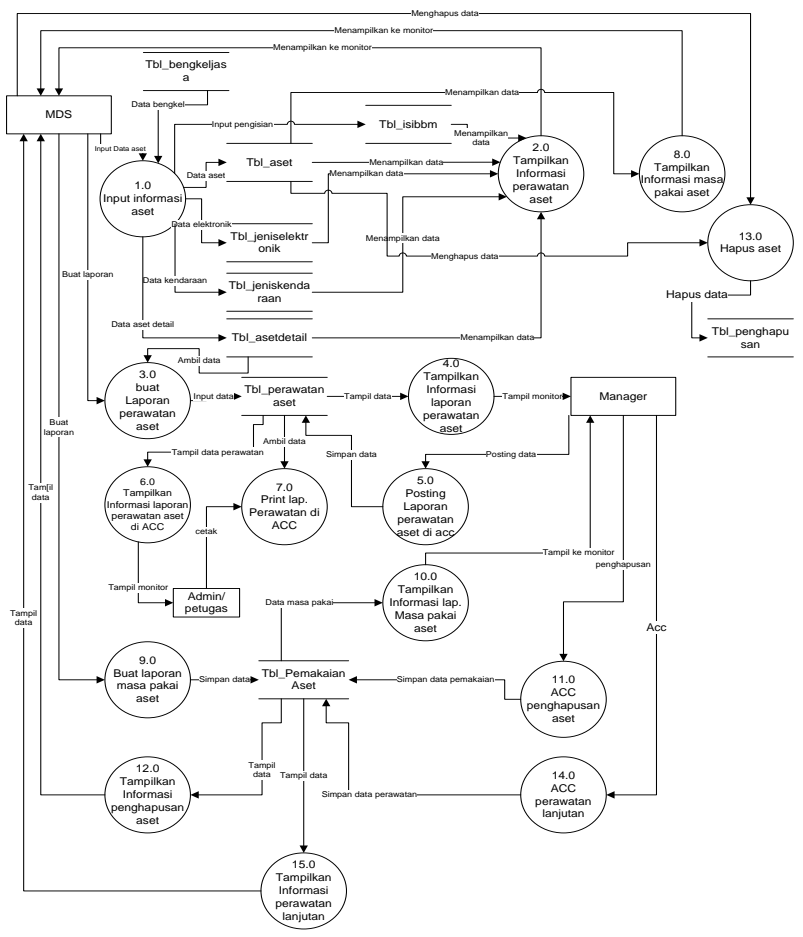

Gambar 4 Data Flow Diagram

\section{ERD}

Entity Relationship Diagram (ERD) merupakan suatu model untuk menjelaskan hubungan antar data dalam basis data berdasarkan objek-objek dasar data yang mempunyai hubungan antar relasi. Lebih jelas dapat dilihat Gambar 5 sebagai berikut:

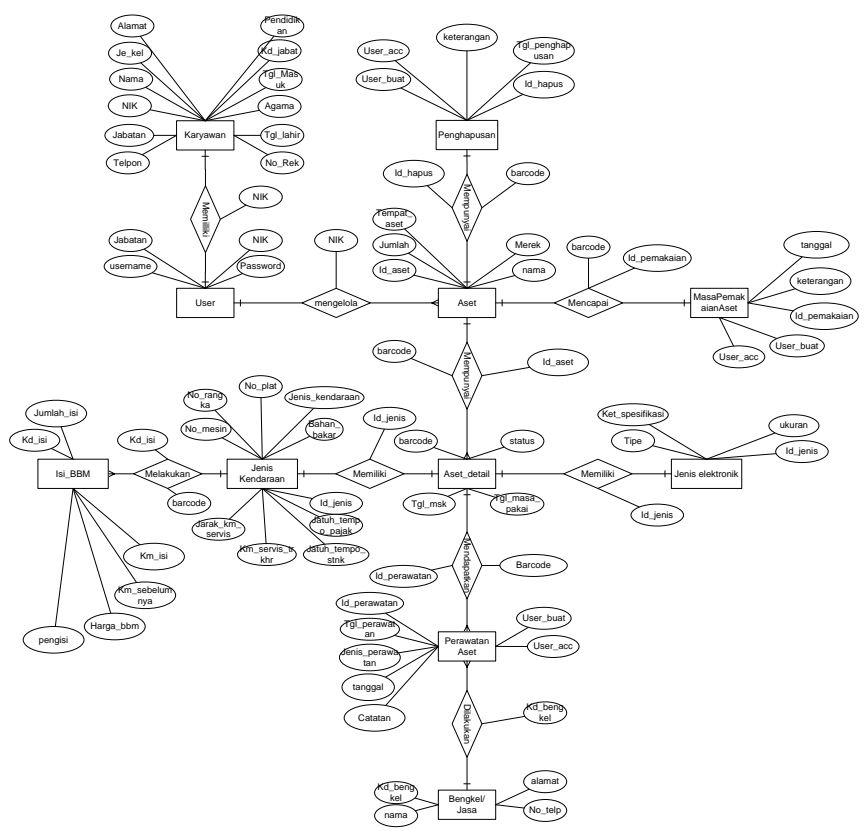

Gambar 5 Entity Relationship Data

\section{HASIL DAN PEMBAHASAN}

\section{Pengujian Sistem}

\section{Form Menu Utama}

Form ini adalah form utama, di form utama ini dapat di akses berbagai form-form di program ini. Dari form master sampai form informasi yang disesuaikan hak aksesnya.

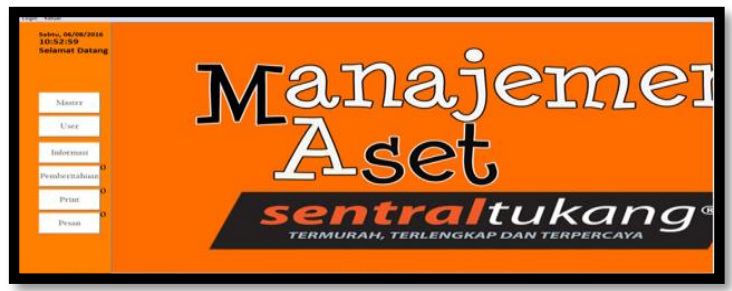

Gambar 6 Tampilan Form Utama

\section{Form Login}

Form login ini akan muncul disaat kita menjalani program pertama kali. Untuk bisa masuk kedalam program, dan berfungsi untuk membatasi hak akses bagi penggunannya. Jabatan yang bisa masuk keprogram ini adalah MDS, ADM, Manager, dan IT.

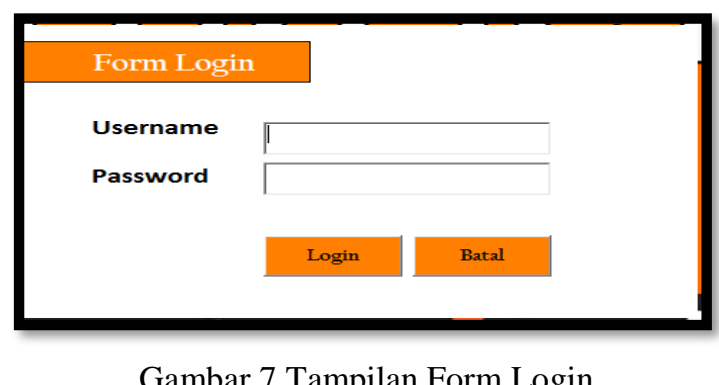

\section{Form Input Karyawan}

Form Karyawan ini berfungsi untuk memasukkan data karyawan perusahaan. Form ini hanya bisa diakses oleh MDS yang mempunyai button yaitu simpan, hapus, baru, dan keluar. Form ini dapat diakses melalui button master lalu button karyawan.

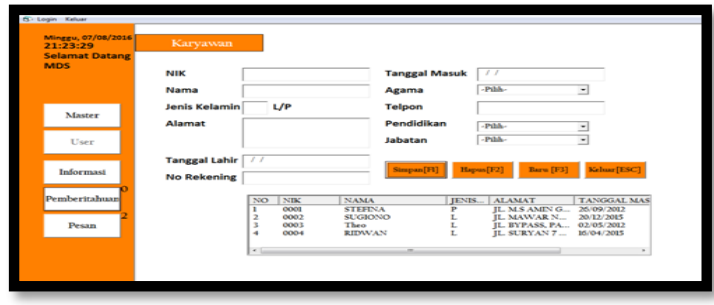

Gambar 8 Tampilan Form Input Karyawan 


\section{Form Input Bengkel Atau Jasa}

Form ini berfungsi untuk memasukkan data bengkel atau pun jasa untuk perawatan aset yang telah ditentukan oleh perusahaan sebelumnya. Form ini juga hanya bisa diakses oleh MDS, didalam form ini terdapat 4 button terdiri dari simpan, hapus, baru, dan keluar.

Form ini dapat diakses melalui button master lalu klik button bengkel.

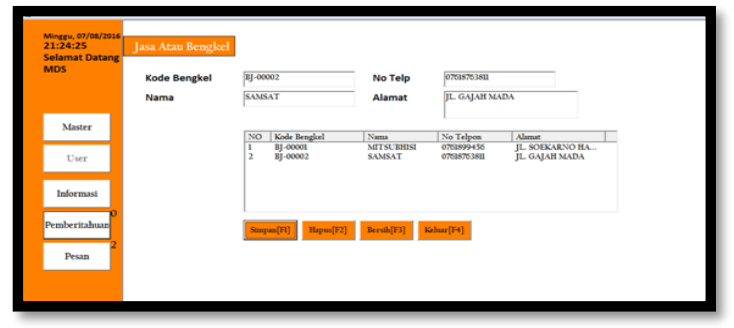

Gambar 9 Tampilan Form Input Bengkel Atau Jasa

\section{Formulir Input Aset Sistem Informasi Manajemen Aset}

Form ini untuk memasukkan data aset yang ada di perusahaan. Dari form ini supaya bisa mendapatkan informasi-informasi tanggal masa pakai, servis, dan perawatan lainnya. Form ini hanya dapat diakses oleh MDS dan mempunyai 4 button yaitu simpan, bersih, keluar dan save all yang akan muncul ketika diklik bersih atau pun memasukkan data baru. Form ini dapat diakses melalui button master lalu klik button aset.

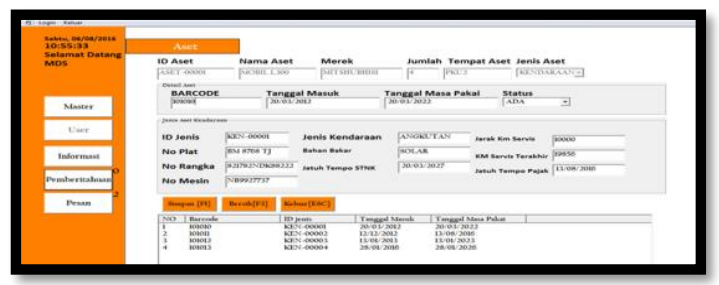

Gambar 10 Tampilan Form Input Aset

\section{Form Informasi Aset}

Form ini berfungsi untuk menampilkan informasi aset, menurut kategori ada, tidak ada, sesuai nama atau bisa menampilkan semua aset. Form ini dapat di akses oleh semua hak akses dapat dilihat tombol informasi lalu klik informasi Aset. Form ini mempunyai 3 tombol yaitu Tambah untuk menambah aset baru dan hanya muncul ketika hak akses MDS, lalu print laporan untuk membuat laporan aset hanya muncul di hak akses MDS, tombol yanmg akan keluar di ketiga hak akses adalah tombol keluar.

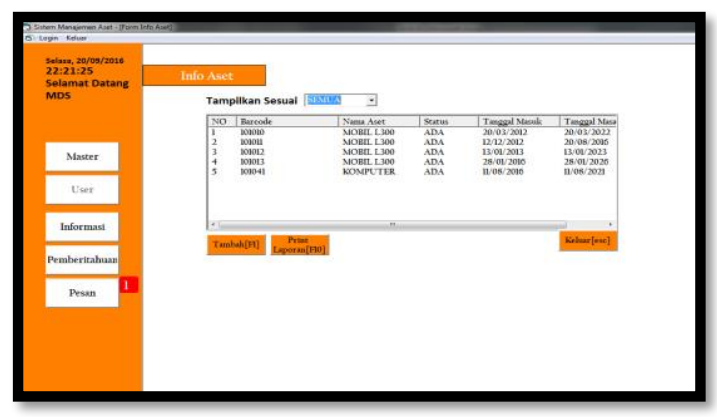

Gambar 11 Tampilan Form Informasi Aset

\section{Form Informasi Perawatan Aset}

Form ini untuk mengetahui informasi aset-aset yang sedang dirawat dan telah dirawat. Form ini juga dapat dilihat oleh semua user, form ini dapat di akses melalui Tombol Master lalu klik Tombol Informasi Perawatan Aset.

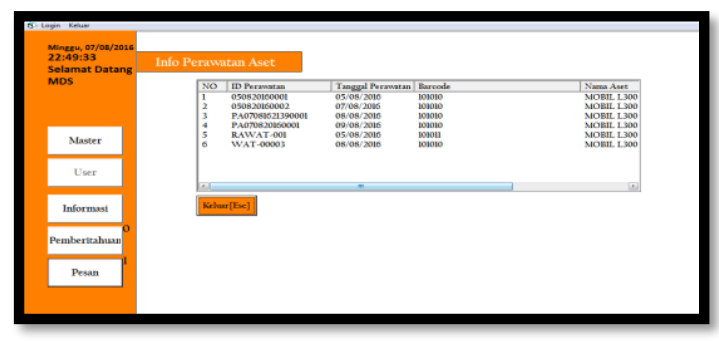

Gambar 12 Tampilan Form Informasi Perawatan Aset

\section{Form Laporan Perawatan Aset}

Form ini adalah keluaran dari laporan perawatan aset yang untuk diarsipkan oleh administrasi. Laporan ini akan muncul ketika semua user telah acc laporan perawatannya, baik dari MDS dan Manager setelah itu akan muncul di hak akses ADM untuk di print lalu ADM print untuk mendapatkan laporan perawatan nya.

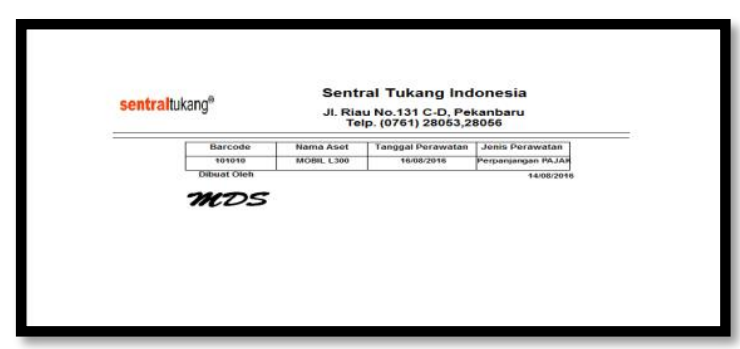

Gambar 13 Tampilan Form Laporan Perawatan Aset

\section{Form Laporan Aset}

Form ini adalah keluaran dari form laporan Aset, yang akan diprint oleh MDS untuk dibuat laporan Pertahunnya. Laporan ini bisa di dapat melalui tombol informasi lalu klik tombol print 
laporan dan otomatis akan mencetak data aset yang ada di perusahaan.

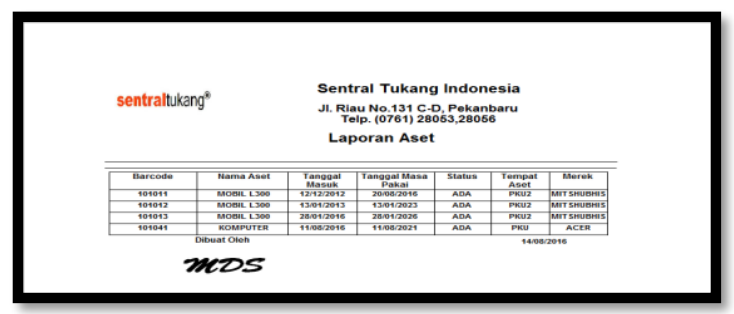

Gambar 14 Tampilan Laporan Aset

\section{Form Pemberitahuan}

Form ini berfungsi ketika ada pemberitahuan laporan yang telah dibuat MDS maka akan muncul pemberitahuan di Manager, sedangkan ketika manager telah acc akan muncul di MDS. Pemberitahuan ini hanya di hak akses manager dan MDS. Dimasing-masing laporan nanti akan muncul notifikasi brp jumlah pemberitahuan yang belum dibaca.

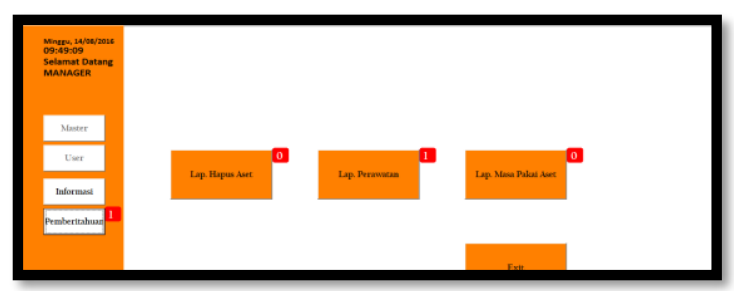

Gambar 15 Tampilan Form Pemberitahuan

\section{Form Pemberitahuan Pesan}

Form ini berada dalam hak akses MDS, yang mana pesan ini tampilkan jika ada aset yang sudah mencapai masa pakai atau sudah mencapai masa perawatannya. Tombol pesan ini akan otomatis menampilkan notifikasi jumlah aset yang telah mencapai masa pakai ataupun yang telah mencapai masa perawatan. Form ini bisa di akses melalui tombol pesan lalu klik aset yang telah mencapai masa perawatannya lalu akan muncul seperti gambar dibawah. Form ini memiliki 3 tombol didalam nya. Buat laporan, untuk langsung ke form lap. Perawatan aset atau ke form lap. Pemakaian aset tergantung dari pesan yang disampaikan. Tampilkan, untuk menampilkan aset yang dinotifikasi tadi. Keluar, untuk keluar dari form atau meninggalkan form ini.

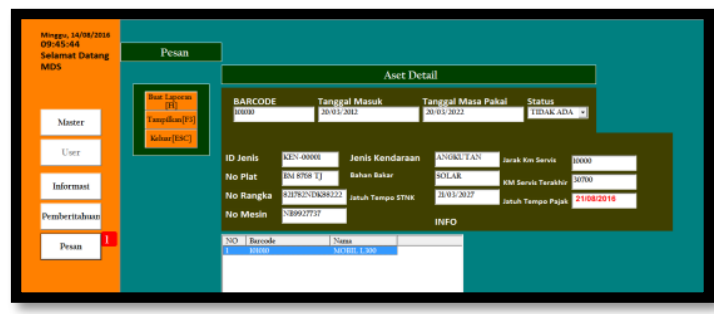

Gambar 16 Tampilan Form Pemberitahuan Pesan

\section{KESIMPULAN DAN SARAN}

\section{Kesimpulan}

Kesimpulan dari penelitian yang berjudul "Sistem Informasi Manajemen Aset di PT. Sentral Tukang Indonesia" adalah sebagai berikut:

1. Sistem informasi ini dapat memonitoring asetaset di PT. Sentral Tukang Indonesia Cabang Pekanbaru.

2. Sistem Informasi ini menjadi alat bantu sebagai pengingat, catatan, pembuatan laporan perawatan, masa pakai, dan penghapusan dalam pengelolaan aset-aset di PT. Sentral Tukang Indonesia Cabang Pekanbaru.

3. Sistem ini berfungsi untuk mengetahui masa pakai aset dan melakukan penghapusan aset jika diperlukan.

4. Sistem ini mendukung pembuatan barcode untuk aset-aset di perusahaan jika ingin menggunakan barcode di setiap aset yang dimiliki.

\section{Saran}

Dalam pembuatan Sistem Informasi Manajemen Aset di PT. Sentral Tukang Indonesia ini masih banyak dapat dikembangkan, seperti:

1. Sistem informasi yang sudah dibangun bisa dikembangkan ke aplikasi smartphone atau pemberitahuan melalui email, supaya pemberitahuannya perawatan aset bisa lebih cepat.

2. Sistem informasi yang dibangun hanya mengedepankan perawatan, penghapusan, dan masa pemakaian aset. Kedepannya supaya dapat dikembangkan dengan penambahan fitur pencatatan pergantian sparepart jika suatu aset telah mencapai masa pakai tapi masih bisa dilakukan perawatan lanjutan.

3. Dapat dikembangkan dengan penambahan password untuk database atau pengamanan yang lebih komplek lagi, serta dapat membuat sistem backup data.

Dapat menambahkan fitur biaya untuk perhitungan biaya perawatan aset dalam sebulan, atau per tahunnya. 


\section{REFERENSI}

[1] Dewi, Gusti dkk. 2013. Rancang Bangun Sistem Informasi Pengelolaan Aset Komputer Dan Peripheral Pada PT. Sucofindo. Stikom Surabaya. Vol 3 No. 3.

[2] Februariyanti, Herny dan Eri Zuliarso. 2012. Rancang Bangun Sistem Perpustakaan untuk Jurnal Elektronik. Jurnal Teknologi Informasi DINAMIK. Vol 12 No 2.

[3] Hoesada, Jan. 2013. Taksonomi Ilmu Manajemen. Yogyakarta: Andi.

[4] Iswandy, Eka. 2015. Sistem Penunjang Keputusan Untuk Menentukan Penerimaan Dana Santunan Sosial Anak Nagari Dan Penyalurannya Bagi Mahasiswa DanPelajar Kurang Mampu Di Kenagarian Barung Barung Balantai Timur. Jurnal Teknotif. Vol 3 No 2.

[5] Jamal, Ahmad dan Lies Yulianto. 2013. Rancang Bangun Sistem Informasi Aplikasi Kasir MenggunakanBarcode Reader Pada Toko dan Jasa Widodo Computer Ngadirojo Kabupaten Pacitan. Indonesian Jurnal on Computer Science. Vol 10 No 4.

[6] Kadir, Abdul. 2014. Pengenalan Sistem Informasi Edisi Revisi. Yogyakarta : Andi.

[7] Mulyanto, Edy dan Slamet Siswanto. 2013. Sistem Informasi Manajemen Aset Pada Universitas Muria Kudus. Jurnal Teknologi Informasi. Vol $9 \quad$ No 1. http://research.pps.dinus.ac.id. 29 Mei 2016

[8] Setyaningrum, Sintha. 2013. Konsep dan Perancangan Basis Data. Yogyakarta : Skripta Media Creative.

[9] Sophian, Sophan. 2014. Pengimplementasian Dan Perancangan Sistem Informasi Penjualan Dan Pengendalian Stok Barang Pada Toko Swastika Servis (Ss) Bangunan Dengan Menggunakan Bahasa Pemrograman Visual Basic 6.0 Didukung Dengan Database Mysql. Jurnal Momentum. Vol 16 No 2.

[10] Tantra, Rudy . 2012. Manajemen Proyek Sistem Informasi. Yogyakarta:Andi. 